\title{
Attributes of Venture Capital Financing Model: The Case of SMEs Growth in Nairobi City County, Kenya
}

\author{
Apuoyo Benson \\ $\mathrm{PhD}$ Fellow \\ Department of Accounting \& Finance \\ Kenyatta University \\ Jagongo Ambrose \\ Senior Lecturer \\ Department of Accounting and Finance Department \\ Kenyatta University \\ Kilika James \\ Senior Lecturer \\ Department of Business Administration \\ Kenyatta University
}

\begin{abstract}
In a growing economy, it is imperative for players along the venture capital financing value chain model to understand the factors at play that may initially seem trivial but have a bearing in the growth of start-ups. A number of scholarly theories assert that venture capital financing contributes to the growth of venture-backed portfolio companies. However, very few have been able to delve into the tail-end latent attributes of venture capital financing that might seem trivial but immensely contribute to SMEs growth in developing economies. In view of this, this study critically analyzes the intrinsic attributes of venture capital financing model: The case of Small and Medium Enterprises (SMEs)growth in Nairobi City County, Kenya. The study adopted both qualitative and quantitative approaches in a sequential mixed research design to identify and analyze underlying factors that influence the growth of venture capital-backed SMEs. The findings from the qualitative approach were used to develop the survey questionnaire. Purposive sampling method was used to identify 79 venture-capital SMEs which had received funding for the last five years in their operations. Out of these, 51 venture-backed SMEs successfully filled and returned complete questionnaires which were analyzed using exploratory factor analysis. Out of the twelve factors identified by the respondents, five factors were extracted using Principal Component Analysis. These five factors were strategic alliances, non-current assets, initial public offerings (IPOs), management buy back and trade sale of the venture enterprise as factors contributing to SMEs growth. The Kaiser-Meyer-Olkin (KMO) measure of the five factor was 0.576 which exceeded 0.50 as recommended by Hair et al (2006) and the Bartlett's Test of Sphericity was statistically significant at $p=0.017$. The results show that two factors: IPOs and Management buy-back were found to contribute to growth of venture capital-backed SMEs with IPOs contributing $32.385 \%$ and Management buy-back 27.301\%, both having cumulative 59.686\% which explains the variance of SMEs growth and the two had eigenvalues of greater than 1. The study concludes that a positive relationship exists between the venture capital exit route and growth of venture capital-backed SMEs. This shows that in venture capital financing, the exit route is quite critical as it provides market for the venture capitalists to recoup their investment back. Cost of venture capital financing too was found to be critical for growth of venture capital-backed SMEs in Nairobi City County, Kenya. The study concluded that availability of clearly defined exit route for venture capitalists in an economy positively influences the growth of venture capital backed SMEs.
\end{abstract}

Key words: Venture capital financing, venture capital investment, cost of venture capital, exit routes in venture capital, SMEs growth, exploratory factor analysis

\section{Introduction}

In recent years, the growth of Small and Medium Enterprises (SMEs) has received considerable attention in entrepreneurial finance. The extensive role of SMEs growth and its contribution to Gross Domestic Product (GDP) of most economies has a profound effect on the global economy which leads to income generation, poverty reduction and employment opportunities (D'Imperio, 2016). To this extent, SMEs growth also contributes to the development of individual characteristics, personalities, and abilities that allow entrepreneurs to prodigiously transform their income into wealth. It is only well performing SMEs and wealthy firms that would bear the seeds for future transformation into large companies and multinational corporations. 
One of the basic tenets in entrepreneurial finance and of importance to managers, owners, financers and shareholders of SMEs in venture capital model is the dilemma regarding the firm's growth (Xiao, Lawson \& North (2013). The study of the effect of venture capital financing on the growth of firms is not a new phenomenon in the field of finance, economics or even entrepreneurship. What makes the study more challenging particularly in developing economies is the epistemological debate as to whether venture capital financing promotes growth of venture capital backed portfolio companies. The situation is further complicated by lack and inaccessibility of proprietary data of venture capital in developing countries. According to Catalini, Guzman and Stern (2017), venture capital financing contributes to the success of the firms in which they invest by providing capital, offering mentorship, performance monitoring, helping or replacing founding teams while connecting firms to possible customers and suppliers. A widely held belief that exists in developed economies such as the USA and most parts of Europe is that venture capital is the foundation of leadership in the commercialization and growth of enterprises (NVCA, 2011). Some cautions, however, have been thrown by the scholarly work of Parhankangas (2012). Parhankangas notes that some studies compare venture capital backed firms with large firms, which by nature are less dynamic and grow more slowly and in some sectors, it might be absolutely impractical if not possible to create an accurate matched sample of non-venture backed firms. In a real situation, it is not feasible to start a company and be ready for a venture capital financing without a substantial amount of external or owner's capital. While a number of studies (Romain \& Van Pottelsberghe, 2004; HIS, 2009; Achleitner \& Klockner, 2005) suggest that the growth of most SMEs is attributable to contribution of venture capital to new ideas, the reverse is also true that the impact of venture capital on SMEs growth may be context-specific. Accordingly, Ueda and Hirukawa (2003) study is able to detect some sector-specific differences in the relationship between venture capital investments and growth and thus exhibits an adverse relationship between innovation growth and venture capital financing and therefore the economic impact of venture capital investment might be over exaggerated. On the other hand, some studies show that venture capital is not known to spur economic growth of firms or regions (Catalini, Guzman \& Stern, 2017; Blum, 2015).

Thus, this epistemology debate inevitably makes venture capital contribution to an economy less significant and therefore necessitates more scholarly research to dissect the quandary of its contribution to firms' growth.

\section{Objective of the Study}

The objective of this study is to empirically analyse attributes of venture capital financing model; the case of SMEs growth in Nairobi City, Kenya.

\section{Literature Review}

The study reviews both theoretical and empirical literatures with a view to finding coherent theories that lay the foundation of venture capital financing and study gaps in the extant empirical works that give a predictive approach in understanding the growth of venture capital backed SMEs. Consequently, two theories and a number of previous studies are reviewed to give a clear perspective.

\subsection{The Agency Theory}

The venture capital financing model is characterized by varying interests of players along the value chain in the venture capital industry. Investors and entrepreneurs in most cases do have different objectives with divergent opinions and this creates conflicts. Agency theory has emerged as a dominant theoretical perspective in understanding the investor-entrepreneur relationship (Arthurs \&Busenitz, 2003; Gompers \& Lerner, 2004). The consequence of information asymmetry in the entrepreneurial concept is the inability to verify outcomes of the actions of the entrepreneur and the inability to write contracts contingent of future states of the world (Kaplan \& Stromberg, 2003). Agency costs arise because the goals of investors and entrepreneurs conflict and probably, investors cannot effectively verify the agent's activities (Eisenhardt, 1989; Jensen \&Meckling, 1976).

These conflicts may relate to return on investments, ownership shares, corporate governance structures and venture capital financing period before exits by venture capitalists. In such circumstances, organizations must find ways to manage conflict of interests and adapt to changes brought by the new financial environment in order to create a balance of checks in the relationship between the entrepreneur and venture capitalist (Wang et al., 2009). These conflicts of interest come a long with a number of financial and management challenges. These may include moral hazards, adverse selection in the management of the enterprises, intentional hurried or delayed exits (Blum, 2015). These circumstances make rationality trivial and give rise to information asymmetry that provides both the entrepreneur and the venture capitalist with the means to engage in opportunistic behaviour (Christensen et al., 2008).

\subsection{Financial Liberalization Theory}

Sulaiman, Oke and Azeez (2012) define financial liberalization as the removal or loosening of restrictions imposed by the government on the domestic financial market. According to McKinnon (1979) and Shaw (1973) financial liberalization theory has the capacity to free financial markets from governments interference. 
In certain economies, the effects of government involvement in the management of certain institutions were slowly becoming medieval with economic growth. McKinnon and Shaw documented the importance of financial liberalization in relation to economic growth. Ever since then, numerous studies have attempted to document the effects of financial liberalization on, inter alia, economic growth, financing constraints, market integration, capital flows and capital structure.

In the venture capital context, financial liberalization is viewed as a set of operation of policy reforms designed to deregulate and transform the financial system and structure with a view to achieving a liberalized market- oriented system within an appropriate regulatory framework which makes it possible for the operation of a number of financial intermediaries in an economy (Jonson \& Sundarajan, 1999). These studies gave rise to the current financial liberalization theory (Berner, Gomez \& Knorringa, 2012). The proponents supporting this theory believe that financial development and economic growth are directly related and are strongly attached to each other. The relevance of the financial liberalization theory in this study is premised on the fact that majority of the venture capital institutional investors in Kenya are foreign owned. According to EAVCA (2016), over 70\% of venture capital firms are foreign owned with investors from Mauritius leading the pack. This is in line with the proponents of financial liberation who argue that more financial resources are generated in a liberalized as opposed to a repressed economy (McKinnon 1973; Shaw 1973, IMF, 2015).

\subsection{Empirical Literature Review}

This study reviews past empirical evidence works carried out in the field of venture capital financing and growth of SMEs undertaken in a number of countries. Contextual and conceptual aspects of the studies are analysed with a view to collaborating the findings as well as finding study gaps that could be used to explain the existence of current phenomena of venture capital financing and growth of SMEs in Nairobi City County, Kenya.

\subsubsection{Venture capital financing method (investment)}

In the recent past, various empirical studies on aspects of venture capital firms in availing resources for the growth of fledgling firms in several countries have been carried out extensively. Some fundamental and salient features of venture capital financing which characterize its relationship with SMEs are financing methods or investment and its staging structure through sequential rounds. In a study investigating the barriers to SMEs innovation capacity in Tanzania, Ndesaulwa, Kikula and Chao (2017) found that with every round of financing, a new capital firm would offer new financial resources to SMEs in exchange of a percentage of the equity shares in SMEs governance structure. These rounds ensure continued availability of the working capital for the SMEs. As a result, a good working relationship between the venture capitalist and the SMEs is cemented through exchange of equity shares. The study findings reveal that rounds of financing are critical for a firm's growth because they also redefine the governance structure of the SMEs they fund in addition to provision of working capital.

Catalini, Guzman and Stern (2017) investigated venture growth with or without venture capital financing in an imperfect capital market where a venture capitalist encounters the challenges of information asymmetry. Active monitoring, staged funding, and syndication were found to alleviate the problem of moral hazard. The net effect is risk reduction in the portfolio of venture capital. When compared to social welfare in the case of upfront funding with monitoring, and in case of staged funding without monitoring, the results show that up-front funding provides greater benefits than staged funding. Further, the study finds that staged funding acts as successful device in controlling information asymmetries. Subsequently, the study finds that syndicated funding combined with active monitoring gives a higher profit to the start up.

This is attributable to venture capitalists free -riding mechanism in monitoring. The empirical finding by Catalini, Guzman and Stern (2017) supports the existence of information asymmetry in venture capital and this corroborates the result of a study by Amit, Brender and Zott (1999).Although it was found that it is almost impossible to totally eliminate these problems of information asymmetry and market risks, skilled SMEs are cardinal to reducing these market failures through capacity building, monitoring and evaluation, the more effective venture capital industry functions the more the growth of firms they fund. Likewise, Amit, Brander and Zott (1999) finding indicates that the problem of moral hazard and asymmetric information affects the accountability and transparency of most firms and the ultimate success of SMEs depends on practical concepts unique to each country.

In an atmosphere of an imperfect capital market confounded with uncertainty and moral hazard, Wang and Zhou (2012) finds that staged financing method is successfully used by Chinese firms to evaluate the moral hazard. Wang and Zhou further reveal some unique results to create a deeper understanding of the performance of venture capital - backed firms and the role of staged financing. They find that staged financing can achieve high efficiency sinceit plays a dual complementary mechanism to contracting and moral hazard. Syndication, where two or more groups of venture capitalists contribute each proportion of the amount needed to finance a small business, is also a critical factor (Wagner, 2017). 
Most financing that involves a syndicate of two or more venture groups, providing availability of more capital for a working capital and follow-on cash needs to an entrepreneur has been found to contribute to firm's growth (Xiao, Lawson \& North, 2013). That is, Xiao, Lawson and North in their study of venture capital in Canada with respect to firms that make more or less extensive use of upfront, staged or syndication financing to reduce investment risk, find that firms struggle to overcome information asymmetry.

As concerns the problem of information asymmetries, moral hazard and adverse selection, Cherif and Elouaer(2014) contend that syndication financing (multiple venture financing) is suitable. The less informed SMEs will be disadvantaged and may end up staying longer with more venture capitalist before their exits. Staged financing makes information known only to one party, which is the venture capitalist. When information is concealed to SMEs, there is a likelihood of delayed growth. From these studies (Cherif and Elouaer 2014; Xiao, Lawson \& North, 2013; Syed, et al., 2012), it is evident that the focus was not on the venture capital -backed SMEs but venture capitalists.

From the foregoing therefore, a factor that needs to be established is that:

Does the type of venture capital financing investment provide venture backed SMEs with opportunities for growth?

\subsubsection{Cost of venture capital financing}

Peneder (2010) carried out a study to determine the effect of cost containment among start-up firms and the results reveal that financial management and more specifically containment of cost of venture capital is the main company's focus and growth fields affected by cost containment measures are not deemed important. Empirical evidence in Peneder's study shows that there are contradicting views and findings with regards to the venture capital costs. A study by Dagogo and Ollor (2009) carried in Nigeria finds no relationship between debt equity and growth of SMEs growth. The study shows that there are no universal agreements as to whether cost containment in venture capital financing contributes to growth of firms. Peneder's (2010) findings fundamentally differ with Douglass (2012) whose findings reveal that with regards to certain sectors of an economy, cost containment tends to improve profitability without interfering with the future growth prospects of firms. Therefore, from the foregoing analysis of various empirical literatures on costs, it is evident that a management dilemma exists while considering revenue growth versus cost containment measures and thus many firms view revenue growth and cost containments as trade off, where a focus on one dimension means less focus on the other. From this empirical analysis on cost of venture capital, the study question is:

Does the cost of venture capital financing positively influence the growth of venture backed SMEs?

\subsubsection{Venture capital exit route}

A great significant contribution of agency theory in venture capital financing is evident during the exit of the venture capitalists (Eldon, 2008). Venture capitalists have varied exit time as determined by number of years in their contract documents. According to Berkery (2007), knowledge of market helps venture capitalists to evaluate the value of a venture when they want to finance and exit. Xiaoquing (2006) notes venture capital firms have both motivation and the capability to help their portfolio firms forge strategic alliances based on the value of the portfolio companies which is also considered as an exit strategy. Firms valuation provides novel insight in an efficient market on value - added service that venture capitalists claim to provide, that is, access to rich network of alliance partners (Wang et al., 2009). Thus, venture capital relies on efficient market theory information, not information generated by either entrepreneur or within the venture capital firm itself to mitigate on the risk factors such as market competitiveness or technology instability (Lindsey, 2008). In the absence of a valuation report, Gompers et al. (2008) observe that many of these risks are exacerbated in young, less -established firms.

Valerio et al. (2013) recognize the effect of efficient market theory when venture capitalists would wish to sell their investments through Initial Public Offerings (IPOs). Valerio et al study finds that during an exit via an IPO, the value of the SMEs is usually fairly stated by the venture capitalists because of the publicly available information. Even though the exact duration varies from one continent to another, the study notes that the recommended average duration of venture capital financing a single enterprise is seven years. The aspect of duration brings the agency theory problem in venture capital financing into broader perspective. While the finding of overstay may seem to contradict the requirement of duration exit in venture capital financing, it is not surprising though, since the ultimate goal for the venture capitalists is to maximize the returns to their funds by making a timely exit rather than securing long-term survival or after exit growth of their portfolio companies. Even though Valerio et al (2013) study finding is surprising, it supports the findings from other studies (Zhang, 2007; Marigart et al., 2002; Burgel, 2002).

Thus, it is evident that there is contrasting empirical literature venture capital on exits. It is no doubt that exit plays an important role in the performance and subsequent growth of venture capital funded SMEs. The study question therefore is: 
Does the availability of venture capital exit route promote the growth of venture backed SMEs?

\subsection{Study Research Design}

The study adopted descriptive research design. The purpose of a descriptive research is to provide a picture of a situation, event or show how things are related to each other and as it naturally occurs (Blumberg, Cooper \& Schindler, 2005). Descriptive research design also provides a study with an opportunity to integrate the use of both qualitative and quantitative research methods. This research study finds descriptive design expedient to provide data and information for understanding of the factors that cause a phenomenon which helps predict future behavior of venture capital financing in the case of SMEs growth in Nairobi City County in relation to venture backed portfolio companies.

\subsection{Research Methodology}

The study used a mix of both qualitative and quantitative research methods to identify and explain inherent venture capital financing attributes responsible for growth of venture backed SMEs. A number of studies have previously used qualitative and quantitative approaches as a sequential mixed method design (Lee, Rajarantnam\&Konar, 2018; Berman, 2017; Creswell \& Creswell, 2013). Therefore, the fusion of the two would help to describe and help to identify the attributes used by venture capitalists and show if there is an existence of a relation in the growth of SMEs and venture capitalists in Nairobi City, Kenya.

\subsection{Sampling and Data Collection}

The target population was all venture backed SMEs operating within Nairobi City, Kenya. The total population was 97 firms. The sample of venture capital-backed SMEs for this study was selected using purposive sampling. This was fundamental as there is no publicly available proprietary database for venture backed SMEs and thus accessing these data depends much on networking within the venture capital industry. Therefore, purposive sampling technique facilitated the choice of a homogeneous sample specific to the characteristics of the particular group of interest, which were subsequently examined in detail.

Primary data were collected through the use of research questionnaires. The questionnaires contained both openended and closed ended questions and were administered to a sample size of 72 venture backed firms covering a period of operation of five years from 2013 to 2017.The choice for the year 2013 was due to the fact that the devolved government of Nairobi City County took effect in Kenya the year 2013 and the effect of economic environment of a semi-autonomous government would be better assessed after its full cycle of a five-years period. Further, the five-year duration was considered adequate to give statistical data for analysis which could reveal a trend in sales revenues and number of employees which were used as measures of SMEs growth in venture capital financing. The respondents were chief executive officers or officers designated by the chief officers of the venture capital-backed SMEs. The research questionnaires were personally administered, a technique which facilitated an opportunity for an explanation in case certain questions within the questionnaire needed some clarification.

\subsection{Data Analysis and Presentation}

All the 72 venture capital backed SMEs completed the questionnaires and returned. After filtering and removing response records with incomplete information and missing values, a total of 51 questionnaire responses were retained giving a response rate of $64.6 \%$. This response rate was good enough to enable data analysis (Kothari, 2004). Statistical Package for Social Sciences (SPSS) was used to analyse the data. Factor analysis where Principal axis factoring method of extraction and promaxrotation was used to identify the latent factors. Promax rotation allows factors to be correlated (Lee, Rajarantnam \& Konar, 2018) and this study expected a correlation among factors or variables of venture capital financing. Kaiser-Meyer- Olkin (KMO) Measure of sampling adequacy and a Scree Plot were therefore used to determine the number of factors to extract. Subsequently, factor loadings were used to determine which items to retain or remove from subsequent analyses. Factors with fewer than three strong loadings $(\leq 0.50)$ are considered to be weak (Costello \& Osborne, 2005). Davis (1971) recommends comparison of the study variables using Pearson's correlation. The study's Pearson's correlations indicate the relationships between variables as shown in Table 1. Finally, the items were factor analysed to establish the interpretability for inclusion within the underlying factor structure as recommended by Beavers et al. (2013). 
Table 1: Correlation Matrix

Correlation Matrix ${ }^{\mathrm{a}}$

\begin{tabular}{|c|c|c|c|c|c|c|c|c|c|c|c|c|c|}
\hline & Variables & Upfront & Staged & Syndication & $\begin{array}{l}\text { Initall } \\
\text { capital }\end{array}$ & CA & NCA & Public offer & Mergers & MBB & Trade sale & Revenues & Employment \\
\hline \multirow[t]{12}{*}{ Correlation } & Upfront & 1.000 & -0.344 & -0.150 & -0.103 & -0.121 & \begin{tabular}{|c|}
-0.148 \\
\end{tabular} & -0.120 & 0.065 & -0.013 & -0.027 & 0.109 & 0.035 \\
\hline & Staged & -0.344 & 1.000 & -0.707 & 0.020 & 0.047 & 0.218 & -0.077 & -0.068 & 0.141 & -0.174 & 0.038 & -0.399 \\
\hline & Syndication & -0.150 & -0.707 & 1.000 & 0.033 & 0.001 & -0.110 & 0.147 & 0.068 & -0.238 & 0.206 & 0.003 & 0.285 \\
\hline & Initail capital & -0.103 & 0.020 & 0.033 & 1.000 & -0.253 & 0.109 & 0.030 & -0.017 & 0.123 & -0.056 & 0.103 & -0.045 \\
\hline & $\mathrm{CA}$ & -0.121 & 0.047 & 0.001 & -0.253 & 1.000 & -0.428 & -0.013 & -0.027 & 0.035 & -0.118 & -0.070 & 0.134 \\
\hline & NCA & -0.148 & 0.218 & -0.110 & 0.109 & -0.428 & 1.000 & 0.234 & -0.112 & 0.114 & 0.162 & -0.136 & -0.004 \\
\hline & Public offer & -0.120 & -0.077 & 0.147 & 0.030 & -0.013 & 0.234 & 1.000 & -0.349 & -0.162 & 0.453 & -0.422 & 0.160 \\
\hline & Mergers & 0.065 & -0.068 & 0.068 & -0.017 & -0.027 & -0.112 & -0.349 & 1.000 & -0.569 & -0.210 & 0.074 & -0.103 \\
\hline & MBB & -0.013 & 0.141 & -0.238 & 0.123 & 0.035 & 0.114 & -0.162 & -0.569 & 1.000 & -0.091 & 0.168 & -0.026 \\
\hline & Trade sale & -0.027 & -0.174 & 0.206 & -0.056 & -0.118 & 0.162 & 0.453 & -0.210 & -0.091 & 1.000 & -0.268 & 0.172 \\
\hline & Revenues & 0.109 & 0.038 & 0.003 & 0.103 & -0.070 & -0.136 & -0.422 & 0.074 & 0.168 & -0.268 & 1.000 & -0.144 \\
\hline & Employment & 0.035 & -0.399 & 0.285 & -0.045 & 0.134 & -0.004 & 0.160 & -0.103 & -0.026 & 0.172 & -0.144 & 1.000 \\
\hline \multirow[t]{12}{*}{ Sig. (1-tailed) } & Upfront & & 0.007 & 0.146 & 0.237 & 0.198 & 0.151 & 0.201 & 0.324 & 0.465 & 0.426 & 0.223 & 0.403 \\
\hline & Staged & 0.007 & & 0.000 & 0.444 & 0.371 & 0.062 & 0.296 & 0.318 & 0.163 & 0.111 & 0.397 & 0.002 \\
\hline & Syndication & 0.146 & 0.000 & & 0.409 & 0.497 & 0.221 & 0.151 & 0.317 & 0.047 & 0.073 & 0.491 & 0.021 \\
\hline & Initail capital & 0.237 & 0.444 & 0.409 & & 0.037 & 0.222 & 0.416 & 0.454 & 0.194 & 0.349 & 0.236 & 0.378 \\
\hline & $\mathrm{CA}$ & 0.198 & 0.371 & 0.497 & 0.037 & & 0.001 & 0.464 & 0.425 & 0.403 & 0.205 & 0.312 & 0.175 \\
\hline & NCA & 0.151 & 0.062 & 0.221 & 0.222 & 0.001 & & 0.049 & 0.217 & 0.213 & 0.128 & 0.171 & 0.488 \\
\hline & Public offer & 0.201 & 0.296 & 0.151 & 0.416 & 0.464 & 0.049 & & 0.006 & 0.128 & 0.000 & 0.001 & 0.131 \\
\hline & Mergers & 0.324 & 0.318 & 0.317 & 0.454 & 0.425 & 0.217 & 0.006 & & 0.000 & 0.070 & 0.303 & 0.235 \\
\hline & MBB & 0.465 & 0.163 & 0.047 & 0.194 & 0.403 & 0.213 & 0.128 & 0.000 & & 0.263 & 0.120 & 0.428 \\
\hline & Sell back & 0.426 & 0.111 & 0.073 & 0.349 & 0.205 & 0.128 & 0.000 & 0.070 & 0.263 & & 0.029 & 0.113 \\
\hline & Revenues & 0.223 & 0.397 & 0.491 & 0.236 & 0.312 & 0.171 & 0.001 & 0.303 & 0.120 & 0.029 & & 0.156 \\
\hline & Employment & 0.403 & 0.002 & 0.021 & 0.378 & 0.175 & 0.488 & 0.131 & 0.235 & 0.428 & 0.113 & 0.156 & \\
\hline
\end{tabular}

a. Determinant $=.028$

Source: Study results of correlation matric (2020).

\subsection{Results}

The KMO measure of sampling adequacy was valued at 0.576 , which was above the value of 0.5 as recommended by Hair et al. (2006). Bartlett's Test of Sphericity showed statistical significance $(p=0.00)$ indicating that sufficient correlations exist among the study variables was significant. Factors with eigenvalues greater than 1 were considered significant. Five factors had eigenvalues of more than 1. Factor loadings values of \pm 0.30 to \pm 0.40 are sufficient for interpretation (Hair et al., 2006). This is supported by Cartell's (1966) Scree test. The study used a factor loading cut-off point of 0.50 for retaining items in the factor analysis. From the initial 12 items, a total of 7 items did not load significantly and subsequently were excluded. The remaining 5 items were factor analysed again, results of which are shown in Table 2.

Table 2: KMO and Bartlett's Test

\begin{tabular}{|lll|}
\hline Kaiser-Meyer-Olkin Measure of Sampling Adequacy. & 0.576 \\
\hline Bartlett's Test of Sphericity & Approx. Chi-Square & 21.736 \\
\cline { 2 - 3 } & $\mathrm{df}$ & 10 \\
\cline { 2 - 3 } & Sig. & 0.017 \\
\hline
\end{tabular}

Source: Study results of KMO \& Bartlett's Test (2020).

Further, the Bartlett's Test of Sphericity indicated statistical significance $(\mathrm{p}=0.017)$, indicating the existence of correlations among the variables. These components were levelled as follows: Venture capital exit route and Cost of venture capital. These two components were found to have a positive significant influence on the growth of venture capital backed SMEs in Nairobi City. The component Venture capital exit route, had 3 items with significant factor loadings ranging from 0.804 for Initial Public Offering, Management buy-back 0.761 and Trade sale 0.596. The other component was Cost of venture capital which had two items: Non-current assets and Strategic 
alliance. Non-current asset had factor loading of 0.713 while Strategic alliance had a negative factor loading of 0.721. These are indicated in Table 3.

Table 3. Rotated Component Matrix ${ }^{\mathrm{a}}$

\begin{tabular}{|c|c|c|}
\hline & \multicolumn{2}{|c|}{ Component } \\
\hline & 1 & 2 \\
\hline Initial public offer & 0.804 & \\
\hline Management buy-back & 0.761 & \\
\hline Trade sale & 0.596 & \\
\hline Non current assets & & 0.713 \\
\hline Strategic alliance & & -0.721 \\
\hline
\end{tabular}

Extraction Method: Principal Component Analysis

a Rotation converged in 3 iterations

Source: Study results of Principal Component Analysis (2020).

The study results analysis confirms that the use of positive effect items and also the promax rotation solution shows the variance which strongly loaded the measurement of items on their respective construct components. The total variance explained shows that Venture capital exit route accounts for $32.385 \%$ while Cost of venture capital accounts for $27.301 \%$ when extraction method is Principal Component Analysis. This is shown in Table 4.

Table 4: Total Variance Explained

\begin{tabular}{|c|c|c|c|c|c|c|c|c|c|}
\hline \multicolumn{4}{|c|}{ Initial Eigenvalues } & \multicolumn{3}{|c|}{$\begin{array}{l}\text { Extraction Sums of Squared } \\
\text { Loadings }\end{array}$} & \multicolumn{3}{|c|}{$\begin{array}{l}\text { Rotation Sums of Squared } \\
\text { Loadings }\end{array}$} \\
\hline Component & Total & $\begin{array}{l}\% \text { of } \\
\text { Variance }\end{array}$ & $\begin{array}{l}\text { Cumulative } \\
\%\end{array}$ & Total & $\begin{array}{l}\% \text { of } \\
\text { Variance }\end{array}$ & $\begin{array}{l}\text { Cumulative } \\
\%\end{array}$ & Total & $\begin{array}{l}\% \text { of } \\
\text { Variance }\end{array}$ & $\begin{array}{l}\text { Cumulat } \\
\text { ive } \%\end{array}$ \\
\hline 1 & 1.702 & 34.048 & 34.048 & 1.702 & 34.048 & 34.048 & 1.619 & 32.385 & 32.385 \\
\hline 2 & 1.282 & 25.639 & 59.686 & 1.282 & 25.639 & 59.686 & 1.365 & 27.301 & 59.686 \\
\hline 3 & 0.792 & 15.843 & 75.529 & & & & & & \\
\hline 4 & 0.702 & 14.048 & 89.577 & & & & & & \\
\hline 5 & 0.521 & 10.423 & 100.000 & & & & & & \\
\hline
\end{tabular}

Extraction Method: Principal Component Analysis.

Source: Study data (2020).

The two components:Venture capital exit route and Cost of venture had eigenvalues of 1.619 and 1.365 respectively and were considered significant because their eigenvalues were greater than 1 and plotted well on scree plot. The result is shown in Figure 1.

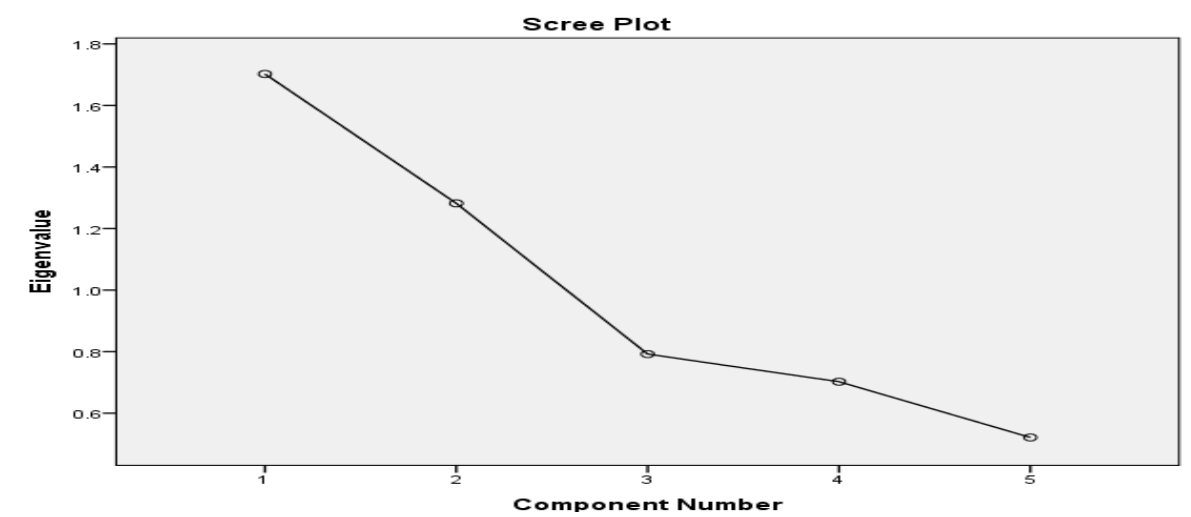

Figure 1: Scree plot

Source: Results of the principal factor analysis (2020).

\subsection{Discussions and Conclusion}

The study established that venture capitalists exit route plays an integral role in the growth of venture backed SMEs in Nairobi City County. This finding in the Kenyan contexts perhaps is an exception and surprising given that almost all venture backed SMEs are not public companies and are not listed at the Nairobi Security Exchange (NSE) where they could trade on securities. Further, an IPO option as a form of exit route would provide the SMEs with limited control when shares get listed and thus dilute the entrepreneurs' ownership. However, the finding is in agreement with a number of studies that venture capitalists would like to use IPOs as an exit route model (Bascha\&Walz, 2001; Schwienbacher, 2002; Parhankangas, 2012; Catalini, Guzman \& Stern, 2017

The result shows that the venture capital financing has latent properties and the complexity of the chosen financing method varies with the anticipated degree of incentive available with the choice of exit route and control problems faced by the contracting parties. The study result shows that an exit through management buy- back as an exit route 
as a choice of debt-financing instrument has a significant and positive effect on growth of venture capital backed SMEs in Nairobi City. Thus, debt-like financing such as management buy- back would tend to be chosen where the agency problems are likely to be low and there is trust between venture capitalists and the management of the SMEs. In management buy-back, the existence of information asymmetry and agency problems is minimal. This result is in agreement with the finding of Bascha and Walz (2001) which notes that silent partnerships and debt financing is most often used if the venture capitalist does not care much about the incentive and control aspects of the exit problem.

Surprisingly, trade sale which is popular exit route in developed countries (Schwienbacher, 2002; Bascha\&Walz, 2001) is found to be the least important in the case study of Nairobi City County. The explanation for this phenomenon could be attributable perhaps to the undeveloped financial market for the sale of venture capital backed firms in Nairobi City County sometimes referred in Kenya as deals.

The study further reveals that cost of venture capital is a critical element of venture capital financing. In the panorama view of entrepreneurship, cost is considered as an expense which contributes to a decrease in the profitability of a firm. Surprisingly, this study shows that is not the case in venture capital. The finding further shows that cost of venture capital is acknowledged as an important dimension of service quality specifically when it concerns human capital development and this is vindicated in a number of studies (Parhankangas, 2017; Wang et al., 2009). The findings lend additional support and credence that trainings proffered to employees of the firm should be viewed as long term investments in venture capital financing resulting in the SMEs growth. The study results show a positive relationship exists between the high cost of venture capital and SMEs growth. This could also be attributed to improvement in skill developments as a way to make the products and services of the firm competitive. Through this way, it cushions the enterprise from technological and product risks which collectively facilitates portfolio companies' growth. To ensure that staff are motivated to provide excellent service and buildlong term customer relationship, venture capitalists usually institute appropriate reward and recognition schemes that would give top managers an opportunity to own a small share of the enterprise and eventually acts as a fall back of an effective exit route through management buy-back and in this case the remuneration is treated as cost item.

The extraction method indicated a negative value for strategic alliance as an exit route for venture capitalists and this shows a negative effect in the growth of venture capital portfolio companies in Nairobi City County. The study attributes this to a number of challenges associated with alliances and mergers (M\&A) in businesses. SMEs view M\&A as impediments wrought with lack of trust, different priority interests of the merging companies, corporate downsizing and re-organizations which will eventually breaks down trusts. This finding corroborates a study by Elmutie et al (2005).

\section{Limitations of the study}

The study however experienced a few limitations. The study encountered lack of reliable and proprietary database as a source of secondary data for venture capital financing in Kenya. Because of this, the study could not possibly cover all the potential venture capital-backed SMEs with the required prerequisite information that could have added more insight. The study recommends further research to interrogate the performance and growth of SMEs post-venture capital financing.

\section{References}

Amit, R., Brander, J. \&Zott, C. (1998). 'Why do venture capital exist?' Journal of Business Venturing, Vol. 13, 441-66.

Association of Venture Capital of Canada (2005). Report on the Performance of Venture Capital in the Canadian Market. Toronto.

Baruch, Y. \& Holtom, B. C. (2008). Survey Response Rate Levels and Trends in Organizational Research. http://hum.sagepub.com/cgi/content/refs/61/8/1139

Bascha, A. \&Walz, U. (2001). Convertible securities and optimal exit decisions in VC finance. Journal of Corporate Finance, 7(1), 285-306.

Beavers, A. S. et al. (2013). Practical considerations for using exploratory factor analysis in educational research. Practical Assessment, Research \& Evaluation, 18(6), 1-13. Retrieved from http://www.parenonline.net/getvn.asp? v=18\&n=6 on 26/3/2020.

Ber, H. (2002). Is Venture Capital Special? Empirical Evidence from a Government Venture Capital Market: Working Paper Series STE- WP-9

Berman, E. (2017). An exploratory sequential mixed methods approach to understanding researchers' data management practice at UVM: Integrated findings to develop research data services: Journal of Escience Librarianship, 6 (1), e1104. 
Berner, E., Gomez, G. \&Knorringa P. (2012). 'Helping a Large Number of People Become a Little Less Poor': The Logic of Survival Entrepreneurs, European Journal of Development Research, 24, 382-396.

Blum, D. A. (2015). Factors contributing to independent venture capital successful exits. Journal of European Economics Association, 5, 93-121.

Blumberg, B., Cooper, D.R., \& Schindler, P. (2005). Business research methods. London: McGraw-Hill.

Bygrave, W.D. \& Timmons, J. A. (2012). Venture Capital at the Crossroads. Boston, Massachusetts: Harvard Business School Press.

Catalini, C., Guzman, J. \& Stern, S. (2017). Hidden in Plain Sight: Venture Growth with or without Venture Capital, Working Paper, MIT.

Catell, R.B. (1966). The scree test for number of factors. Multivariate Behavioral Research, 2(1), 245-276.

Cherif and Elouaer, M. (2014). Venture Capital Financing: A theoretical Model: Journal of Applied Business \& Economics 1(1), 43-56.

Costello, A. B. \& Osborne, J. W. (2005). Best practices in exploratory factor analysis: Four recommendations for getting the best from your analysis. Practical Assessment, Research \& Evaluation, 10, 1-9. Retrieved from: http://pareonline.net/getvn.asp on 27/3/2020

Creswell, J.W. (2014). Research Design: Qualitative, quantitative and Mixed Methods Approaches. New York,NY: Creswell Publications.

Creswell, J. \& Plano, C. (2007). Designing and conducting mixed methods research, Thousand Oaks. CA: Sage.

D'Imperio, R. (2016). Growing the global economy through SMEs. http://www.edinburgh-group.org/media/2776/edinburgh_group_research__growing_the_global_economy_through_smes.pdf(28/05/2016)

East Africa Venture Capital Association (2018). The performance of Venture Capital in East Africa, Annual Report. Nairobi: KPMG.

Field, A. (2013). Factor Analysis using SPSS. Research Methods II. C8057

Gervasoni, A. \&Bollazzi, F. (2012). Developing venture capital activity to promote entrepreneurial competitiveness: Italy's case history.

Gompers, P. \& Lerner, J. (2004). The VC Cycle. Cambridge, MA: The MIT Press.

Hair, J.F. et al., (2006). Multivariate Data Analysis, $6^{\text {th }}$ Ed. New Jersey: Person Educational Fund.

Johnston, R. B., \&Sandarajan, V. (1999). "Sequencing Financial Sector Reforms, Country Experiences and Issues", International Monetary Fund, Washington D.C

Kaminsky, G. L., \&Schmuker, S.L. (2002). "Short-Run Pain, Long-Run Gain; The Effects of Financial Liberalization", IMF Working Paper WP/03/34. Washington D.C

Kaplan, S. N. \& Stromberg, P. (2003). Financial Contracting Theory Meets the Real World: An Empirical Analysis of VC Contracts. Review ofEconomic Studies, 70(2), 281-315.

Lee, M., Rajaratnam, S. D. \&Konar, R. (2018). Key Attributes of Malaysian Specialty Coffee Shops: An Exploratory Investigation. APJIHT Vol.7. No 2 pp. 69-83

Mckinnon, R. I. (1973). Money, Capital and Banking in Economic Development, Brooklyn Institution, Washington D.C.

National Venture Capital Association (NVCA) (2011). National Venture Capital Association Year Book, A Report Prepared by Thomson Reuters for National Venture Capital Association.

Ndesaulwa, A., Kikula, J. \& Chao, E. (2017). Investigation of Barriers to SMEs Innovation Capacity in Tanzania: Can Technology and R\&D Mitigate Their Effects? Journal of Business Sciences, 5(1), 11-17.

Parhankangas, A. (2012). The Economic Impact of Venture Capital. University of Illinois, Chicago, USA.

Peneder, M. (2010). The Impact of Venture Capital on Innovation Behaviour and Firm Growth, Venture Capital, Vol. 12 (2) 83-107.

Romain, A. \& Van Poltelsberghe, B. (2004). The Economic Impact of Venture Capital, Discussion Paper 1: Studies of Economic Research Centre No 18/2004 Deutsche Bundesbank.

Schwienbacher, A. (2002). An Empirical Analysis of Venture Capital Exits in Europe and IN the United States. University of Namur, Belgium.

Shaw, E. (1973). Financial Deepening in Economic Development, Oxford University Press, New York.

Sulaiman, L.A., Oke, M.O. \& Azeez, B. A. (2012). Effects of Financial Liberation on Economic Growth in Developing Countries: The Nigerian Experience. The International Journal of Economics and Management Sciences, Vol.1 No 12 pp16-28.

Syed, A. A., Ahmadalani, M.M., Shaikh, N. \& Shaikh, F.M. (2012). Impact Analysis of SMEs Sector in Economic Development of Pakistan: A case of Sindh. Journal of Asian Business Strategy, 2(2), 44-53.

Ueda, M. \&Hirukawa, M. (2003). Venture Capital and Productivity, Working Paper, University of Wisconsin, Madison.

Valerio, J. (2013). Performance of Canadian Firms that Received VC Financing. Toronto: Canadian Venture Capital and Private Equity Association. 
Venture Capital Association of Canada (2013). Venture Capital Performance in Canada. Toronto: Thompson Reuters.

Wang, H., Wuebker, R.J., Han, S. \& Ensley, M.D. (2009). Strategic alliances by venture capital firms: an empirical examination. Small Business Economics, 38, 179-196.

Wang, S. \& Zhou, H. (2012). Staged Financing in Venture Capital: Moral Hazard and Risks.

Xiao, L., Lawson, M. \& North, D. (2013). Influence of entrepreneurial teams on the growth orientation of early stage high tech SMEs in China: Multiple measures of performance. The International Journal of Entrepreneurship and Innovation, 57(1), 578-582

Zhang, J. (2007). "Access to Venture Capital and the Performance of Venture-Backed Start-Ups in Silicon Valley", Economic Development Quarterly Vol. 21 (2) 124-147

Xiaoqing, E. (2006). Venture Backed IPOs and the Exiting of Venture Capital in China, Journal of Entrepreneurial Finance and Business Ventures, 11(1). 